\title{
OPS CHERT CONUNDRUMS IN FRANCISCAN COMPLEX ACCRETIONARY UNITS
}

\section{LOREN A. RAYMONO}

Coast Range Geological Mapping Institute, Santa Rosa, California \& Department of Geology, Appalachian State University, Boone, NC 28607 raymondla@bellsouth.net

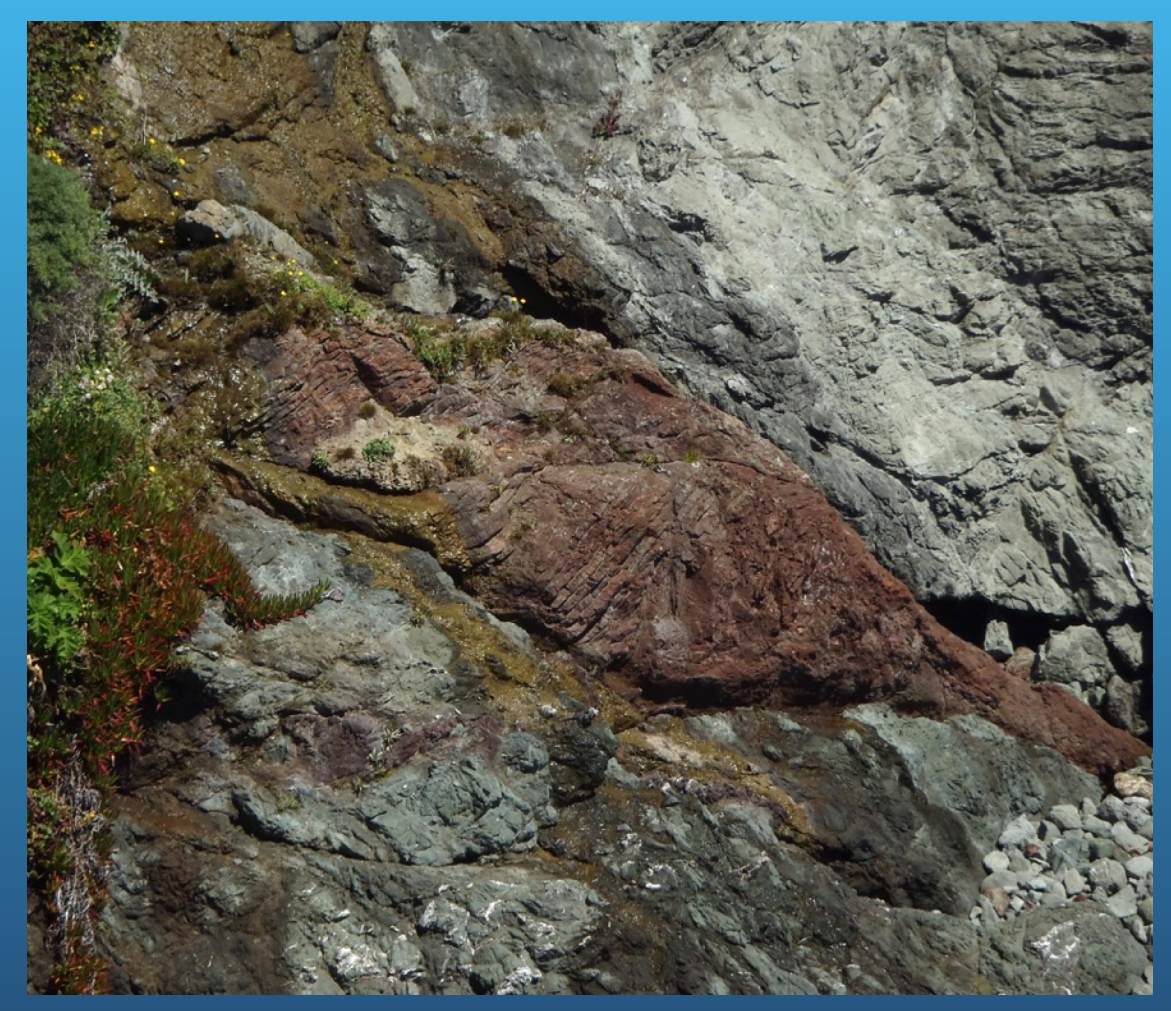




\section{TWO CHERT CONUNDRUMS}

Two chert conundrums, posed as questions, challenge understanding of the accretionary complex architecture and history of the Franciscan Complex of California and SW Oregon.

1) Are all Franciscan chert sections fragments of the same single and areally extensive diachronous pelagic depositional unit?

2) Are all Franciscan cherts parts of OPSs or are some reported over the past 100 years as being interlayered with sandstones in sedimentary sections, actually interlayered? 


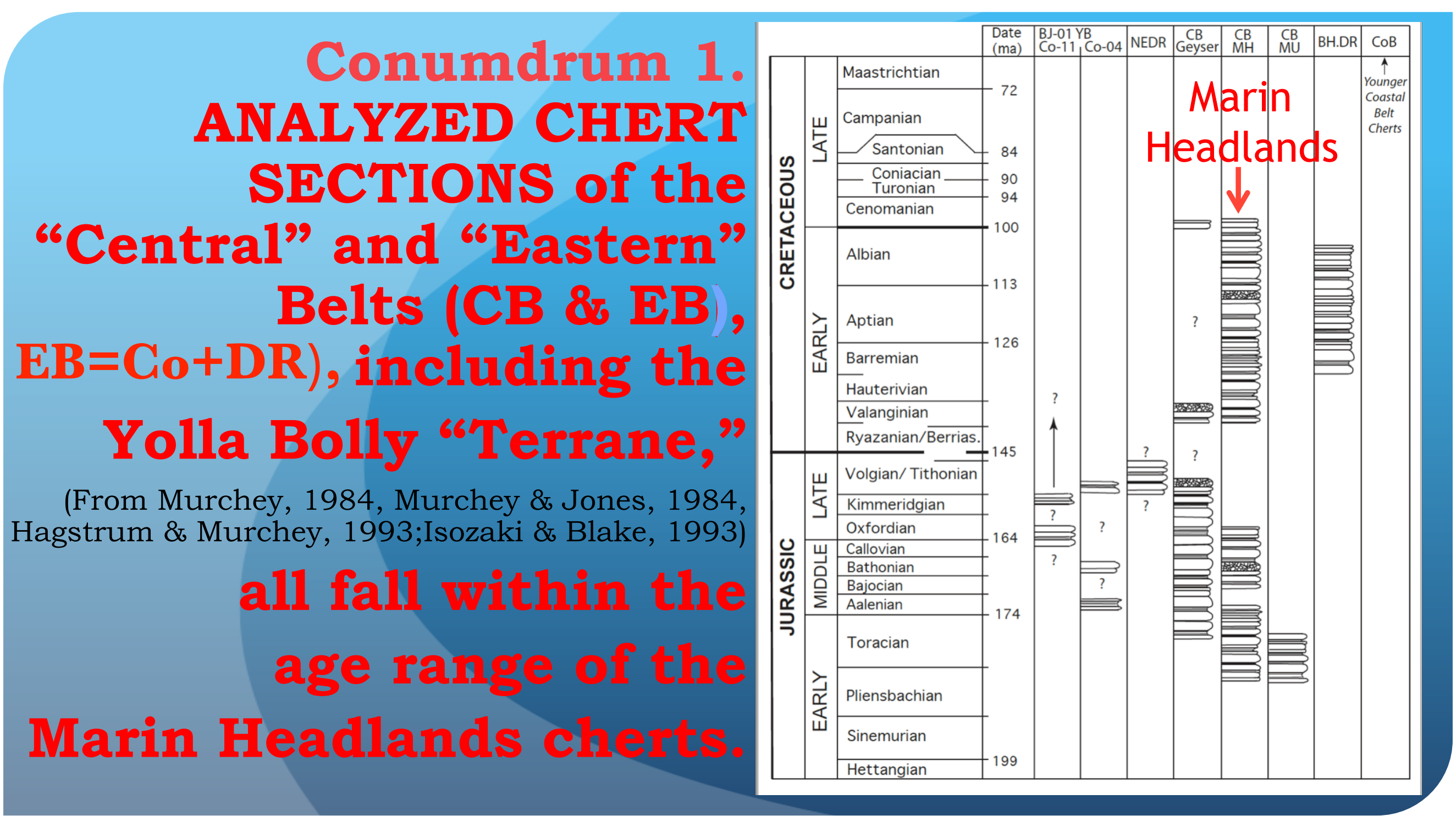




\section{Implications of chert sections and paleomagnetism}

- Paleomagnetic studies suggest that the CB \& EB cherts were deposited in an equatorial zone of high productivity (Hagstrom \& Murchey, 1993).

- If CB \& EB chert, including Marin Headlands chert, was deposited in an equatorial zone of high productivity, that depositional zone seemingly remained in the tropical zone of high productivity about 85 million years (as projected by Hagstrom \& Murchey, 1993). 


\section{Implications of chert sections and paleomagnetism}

- If the EB \& CB cherts are similar in age, they all be part of one large diachronous formation deposited on a moving plate (regardless of the ag of the underlying basalt)?

- But current evaluations of plate movements show 


\section{a}

Initiation of chert deposition in equatorial zone $60^{\circ} \mathrm{N}$
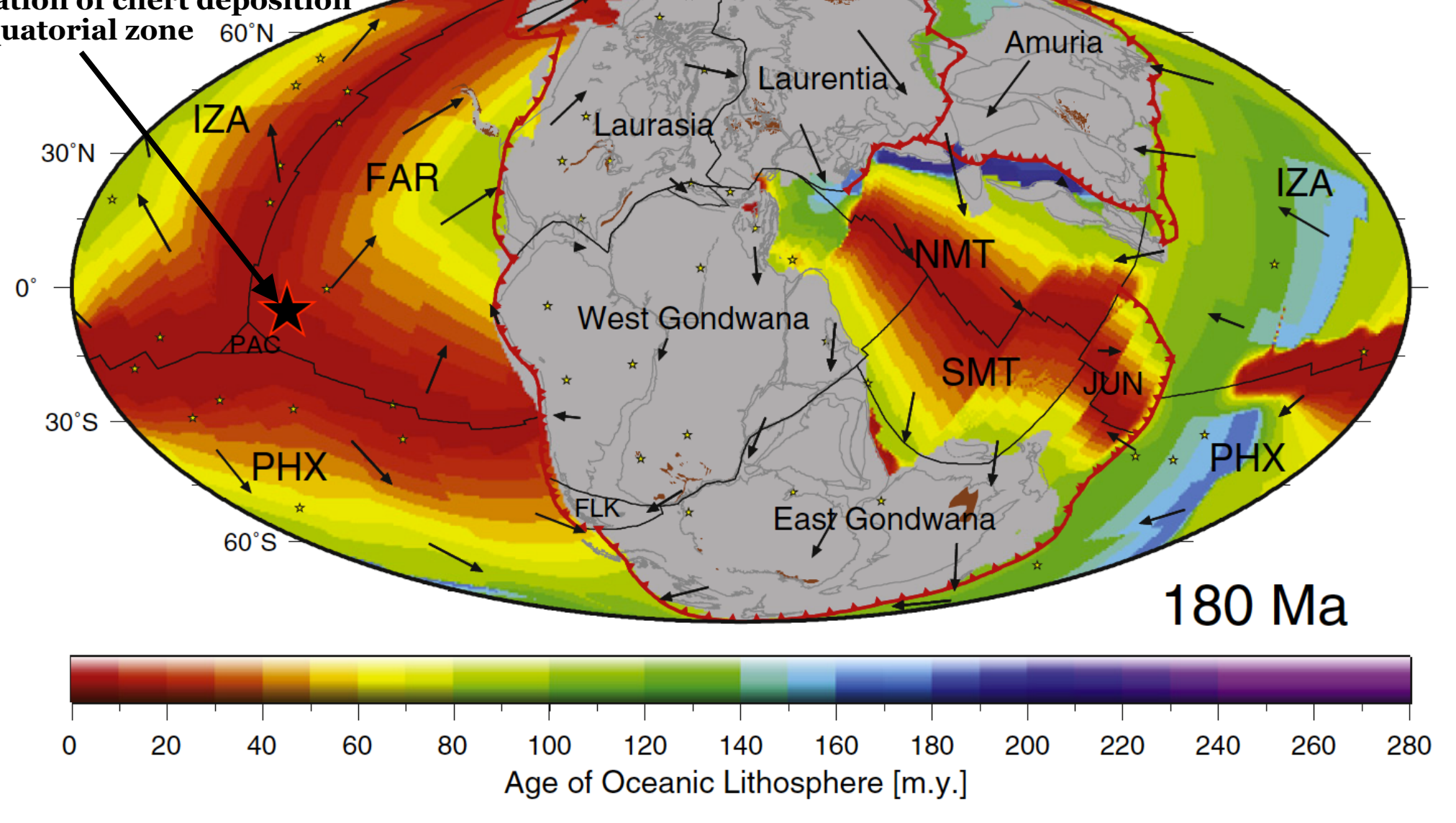

Modified from Seton et al., 2012 

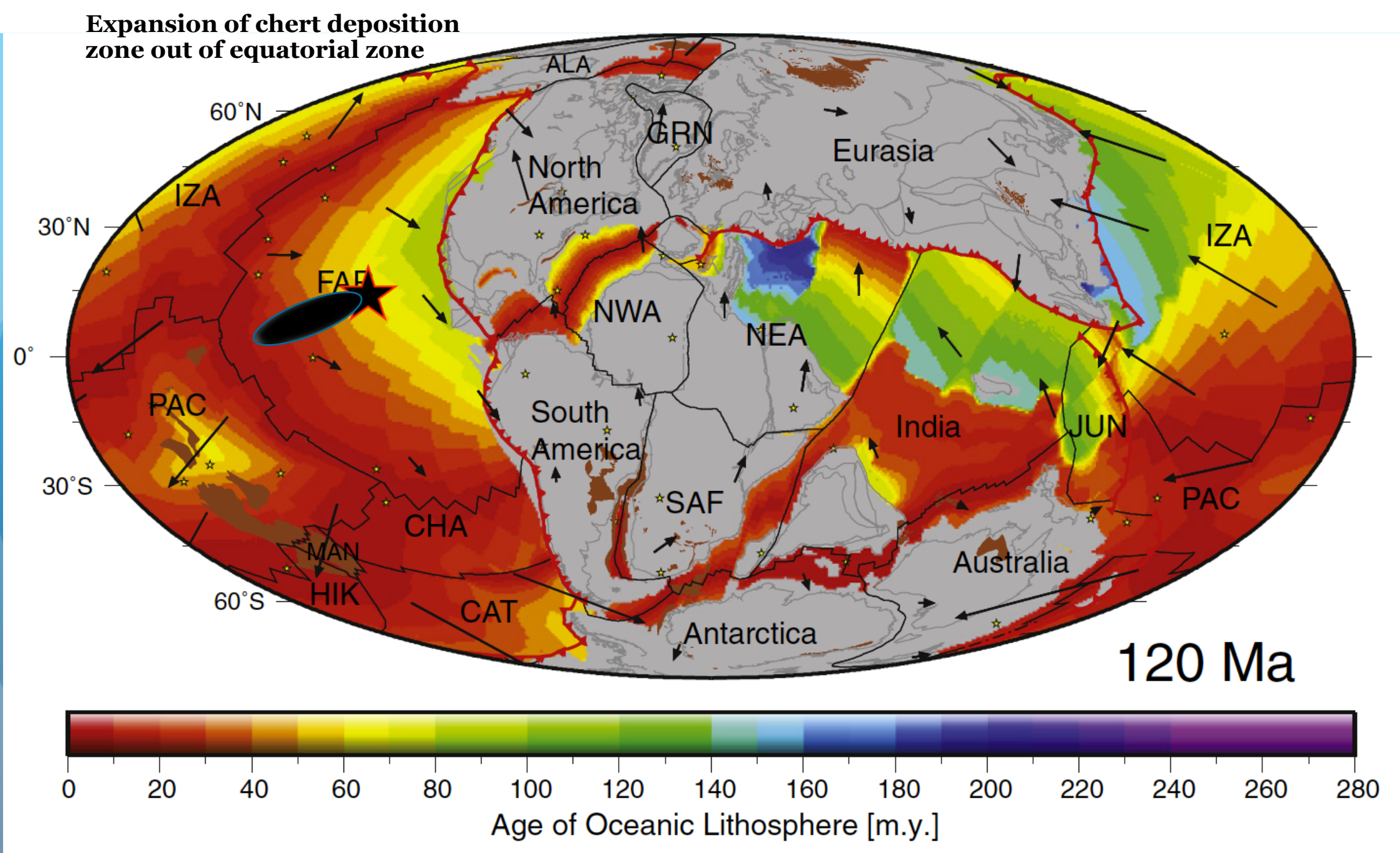

Modified from Seton et al., 2012 
Slightly early collision of diachronous chert

layers with southern North America
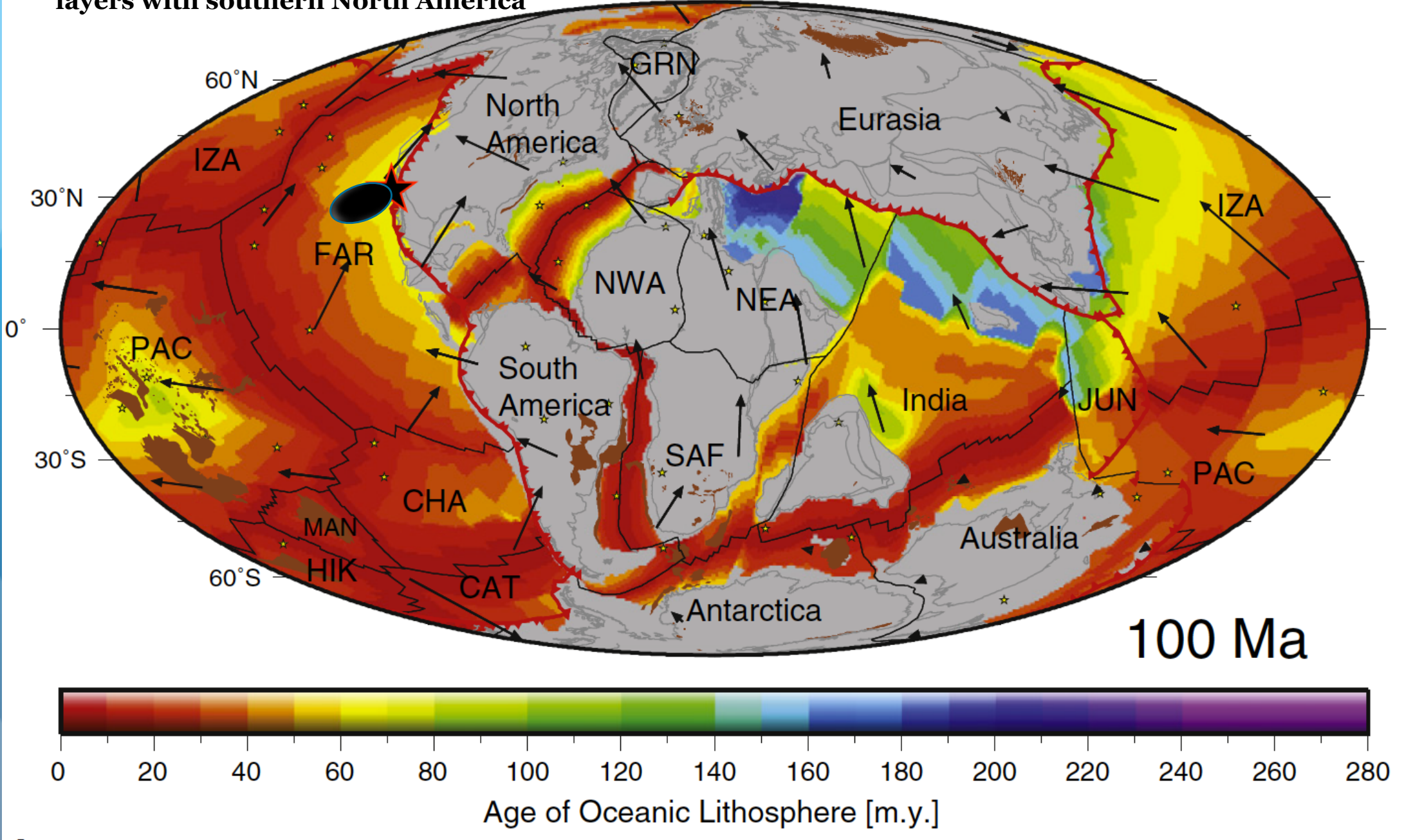

Modified from Seton et al., 2012 


\section{So that SOME PROBLEMS EXIST}

- The oldest chert sections seem to have left the zone of high productivity by $120 \mathrm{Ma}$, but chert continued to be deposited, according to the sedimentary record.

- In current models, the chert seems to arrive at the subduction zone a bit soon.

- The chert and associated subducted sandstone-shale units seem to accrete too far south to have sediment provenance in the Sierra Nevada. 
- In addition, the cherts, as parts of OPS sections, are generally thought to be faulted into several

Franciscan terranes, belts, nappes, or other units.

- For example, the chert shown in the attached sketch, is thought to be faulted into the Yolla Bolly Terrane and against a basalt dike (Isozaki and Blake, 1993)...........but...
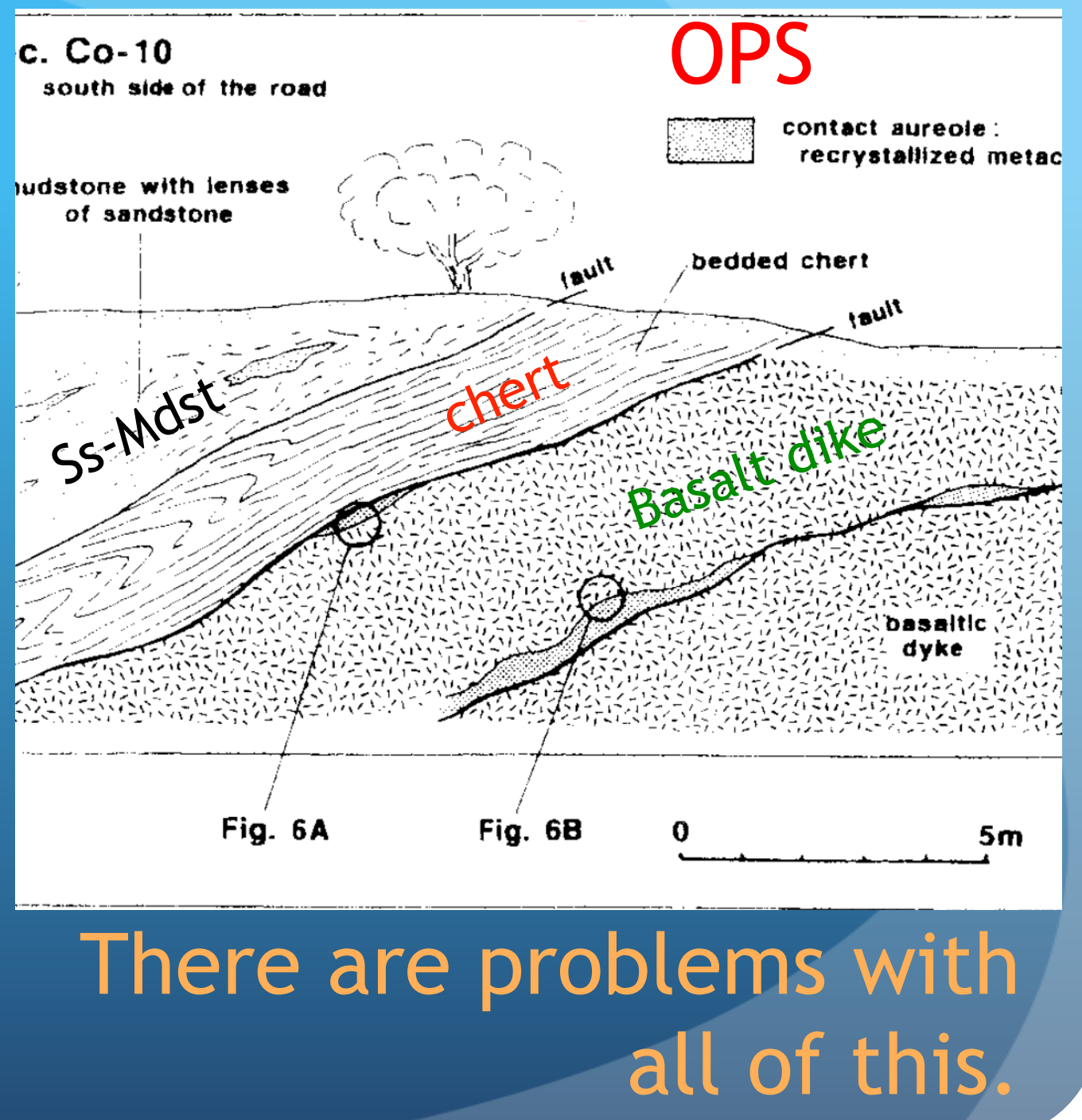


\section{Since, "Tectonostratigraphic terranes [are]...}

defined as fault-bounded geological entities of regional extent, each characterized by a geologic history that is different from the histories of contiguous terranes." (Howell et al., 1984); and if all or many $C B$ \& EB chert sections are fragments of one large, areally extensive diachronous pelagic depositional unit (a very large formation); 


\section{Other Issues \& Questions}

- Did a wider zone of high productivity exist in the Jurassic-Cretaceous?

- Are the paleomagnetic data correct?

- How did the chert get dispersed into and accreted with several different accretionary units?

- Are there chert sections of younger age resting on substantially younger ocean crust that were not part of the large diachronous Marin Headlands chert formation (e.g., Nicasio Reservoir Accretionary Unit)? 


\section{The answers are important, but the}

largest problem is that all units with cherts stratigraphically correlative with the Marin Headlands Terrane must be parts of one terrane, NOT parts of several different terranes (or AUs). Franciscan terrane assignments must be re-evaluatec. 


\section{Conundrum 2}

Are all Franciscan cherts parts of an OPS? Or

are some cherts, as reported over the past 100 years as being interlayered with sandstones in sedimentary sections, actually interlayered?

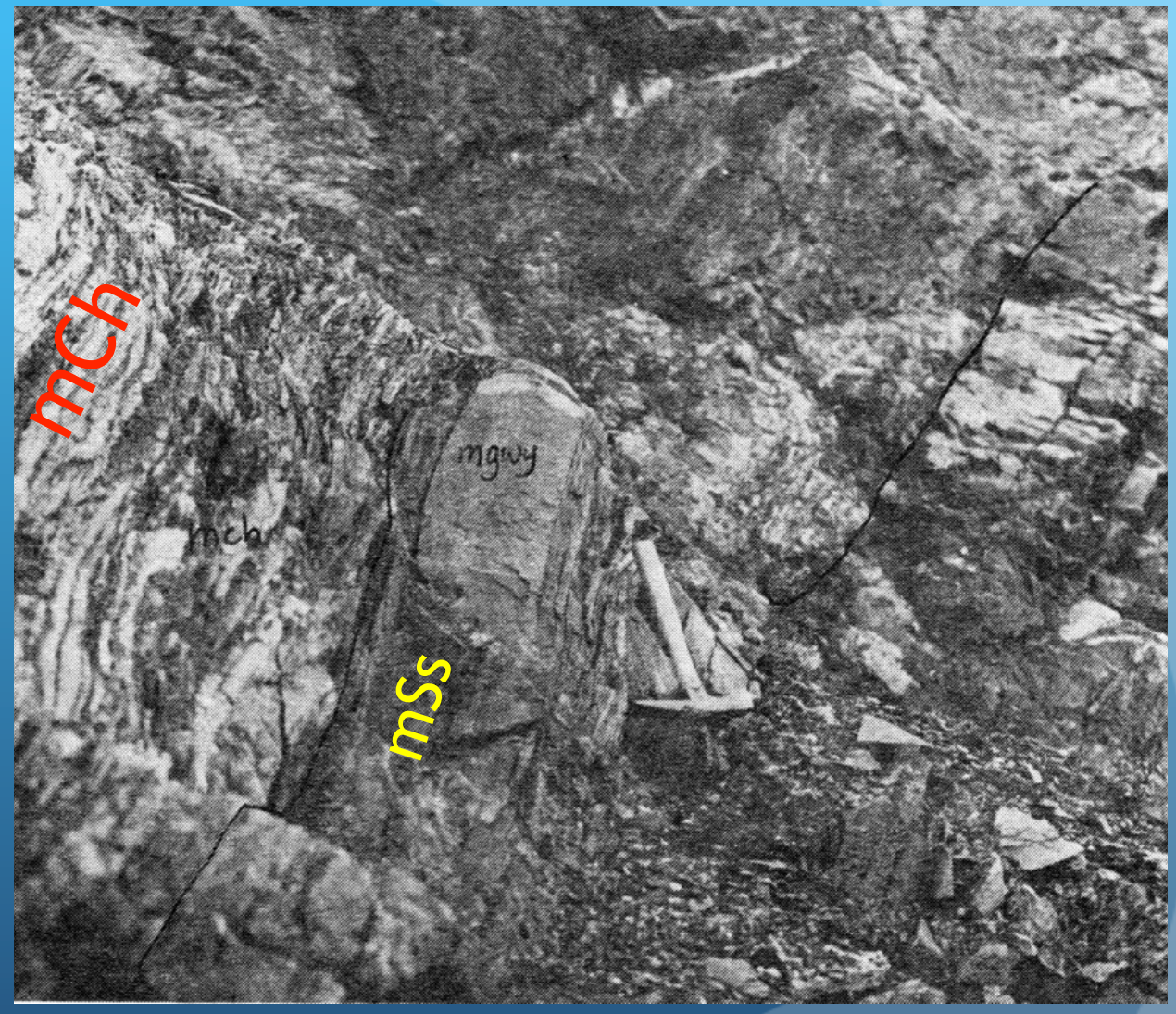

(from Blake et al.,1984) 


\section{Some authors citing interbedded chert}

and sandstone in Franciscan sections

- Davis, 1918; Crawford, 1976;

- Taliaferro, 1943;

- Snetsinger, 1976;

- Gealey, 1951;

- Blake et al., 1982b; 1984;

- Ernst et al., 1970;

- Heubner and Flohr, 1990;

- Raymond, 1973a; 1974;

- Wakabayashi, 2015 


\section{NE Diablo Range}

Raymond (1974) reported this metamorphosed section.

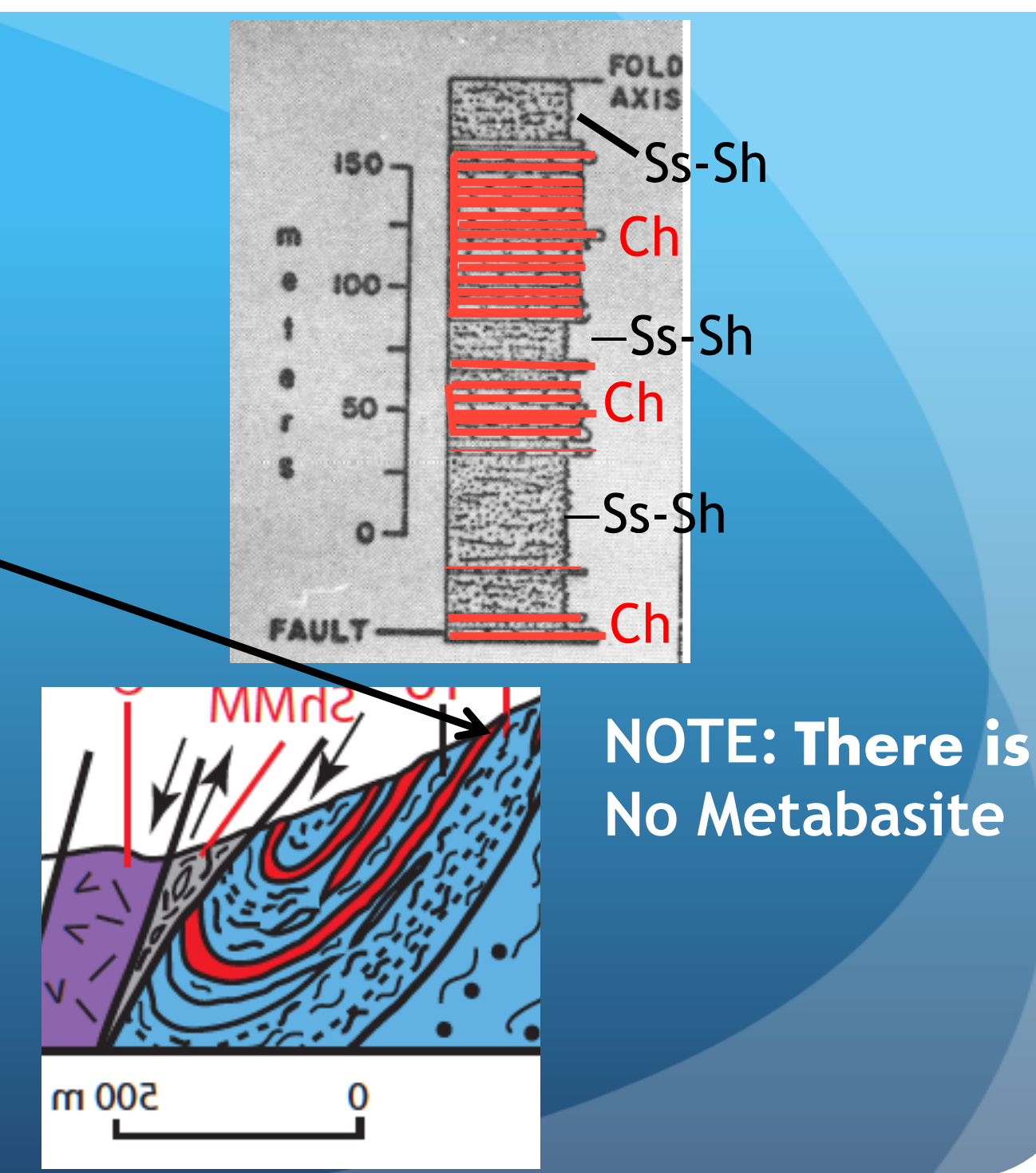


We know that much Franciscan chert was deposited on metabasite as parts of OPS,

\section{e.g., in the Marin Headlands}
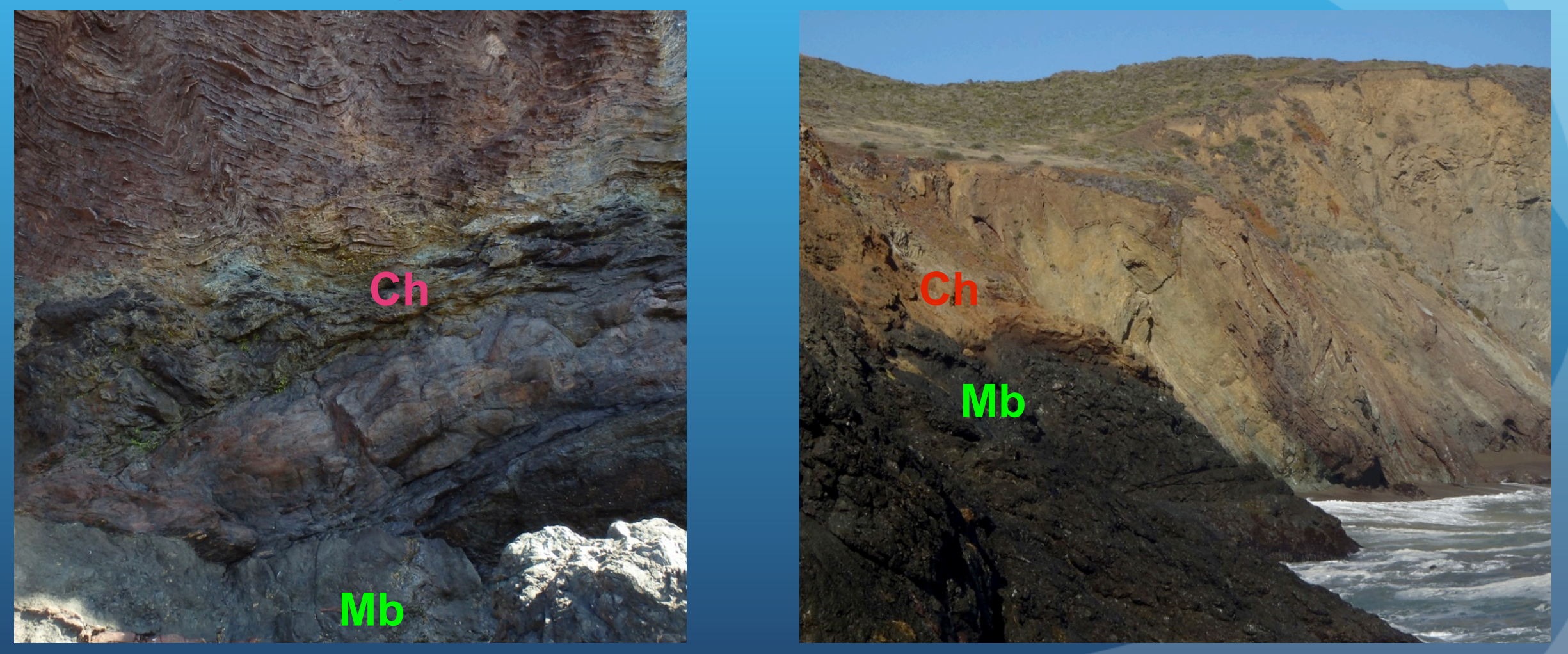
In addition, there are many chert occurrences in which chert was very likely deposited on

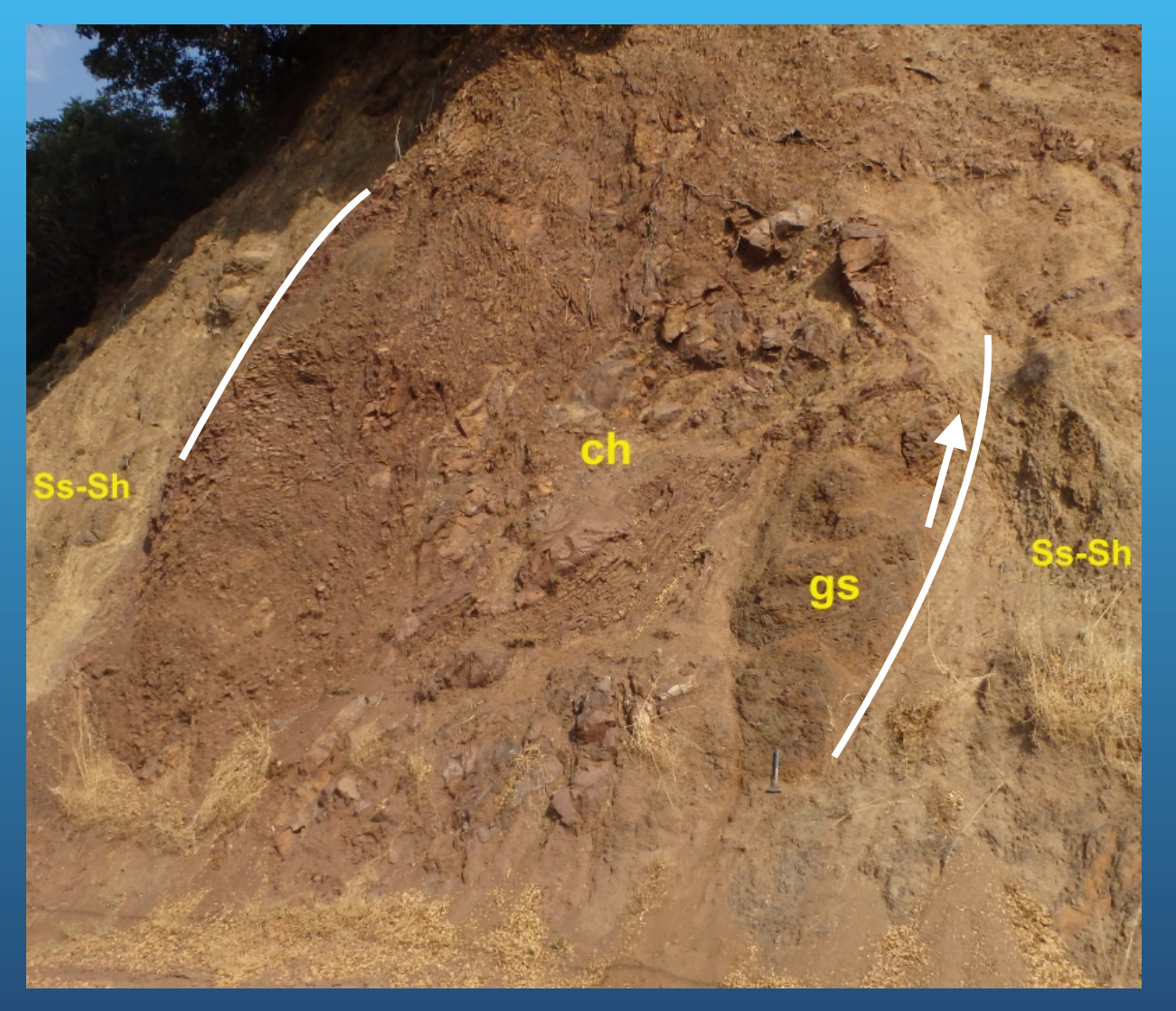

\author{
metabasite, \\ but now has \\ faulted contacts.
}

- This is a fragment of an OPS in a melange near Ukiah. 
Similarly, this Sonoma Coast chert was very likely deposited on the underlying metabasite,

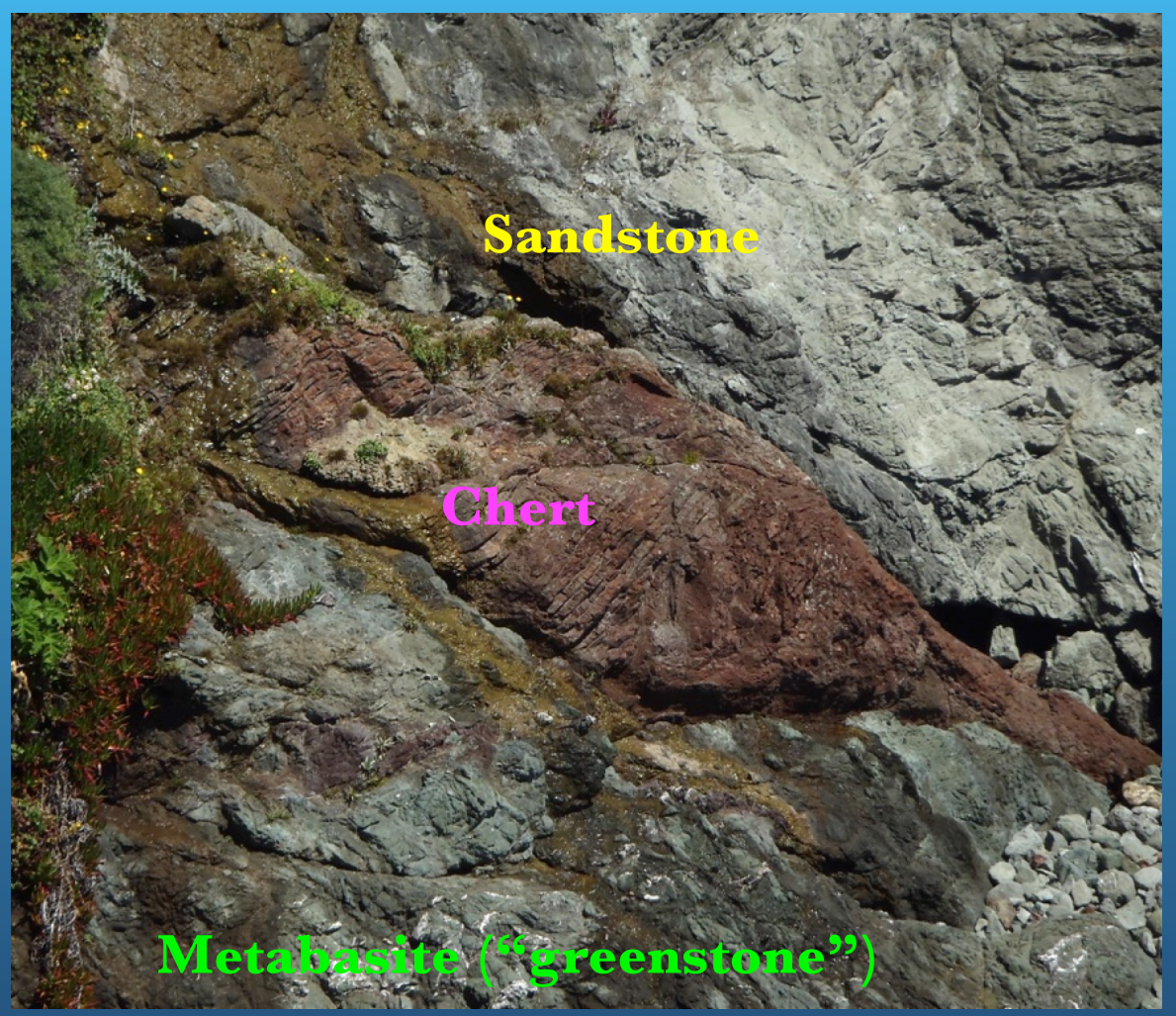

but now the contacts are faulted.

- This is a fragment of an OPS in the Heaven's Beach Melange. 
There are also occurrences of chert faulted against sandstone-shale, with no metabasite nearby, but what is the magnitude of the separation? If it is minor, then the cherts are a part of the stratigraphy.
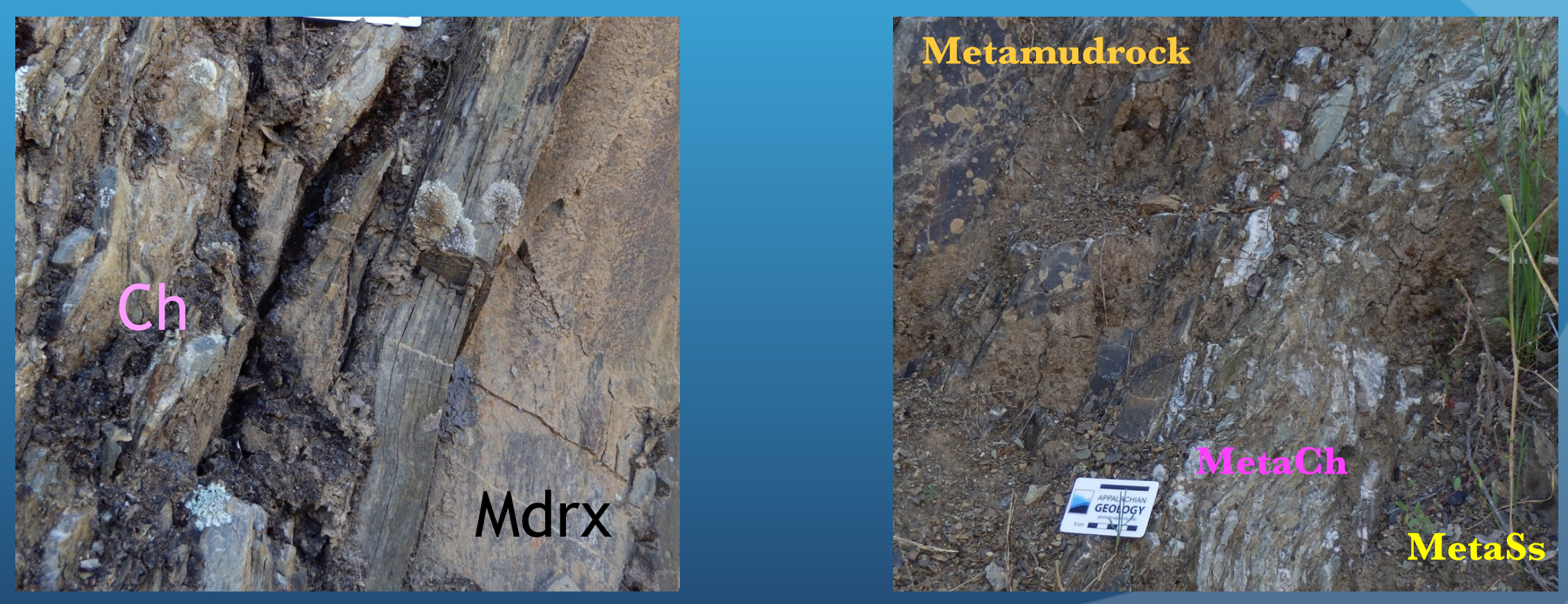


\section{Some chert appears to be clearly}

interlayered with sandstone and shale

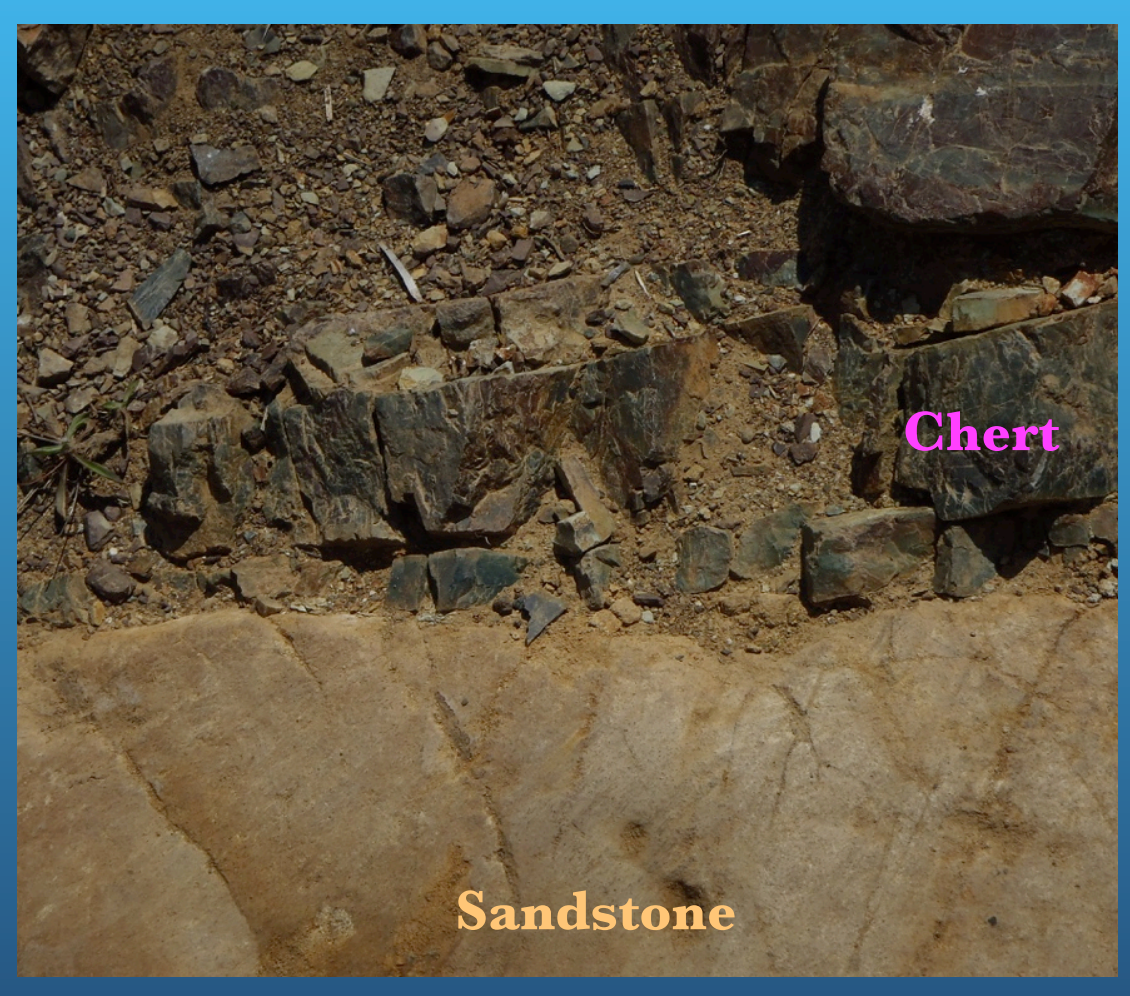

Marin Headlands

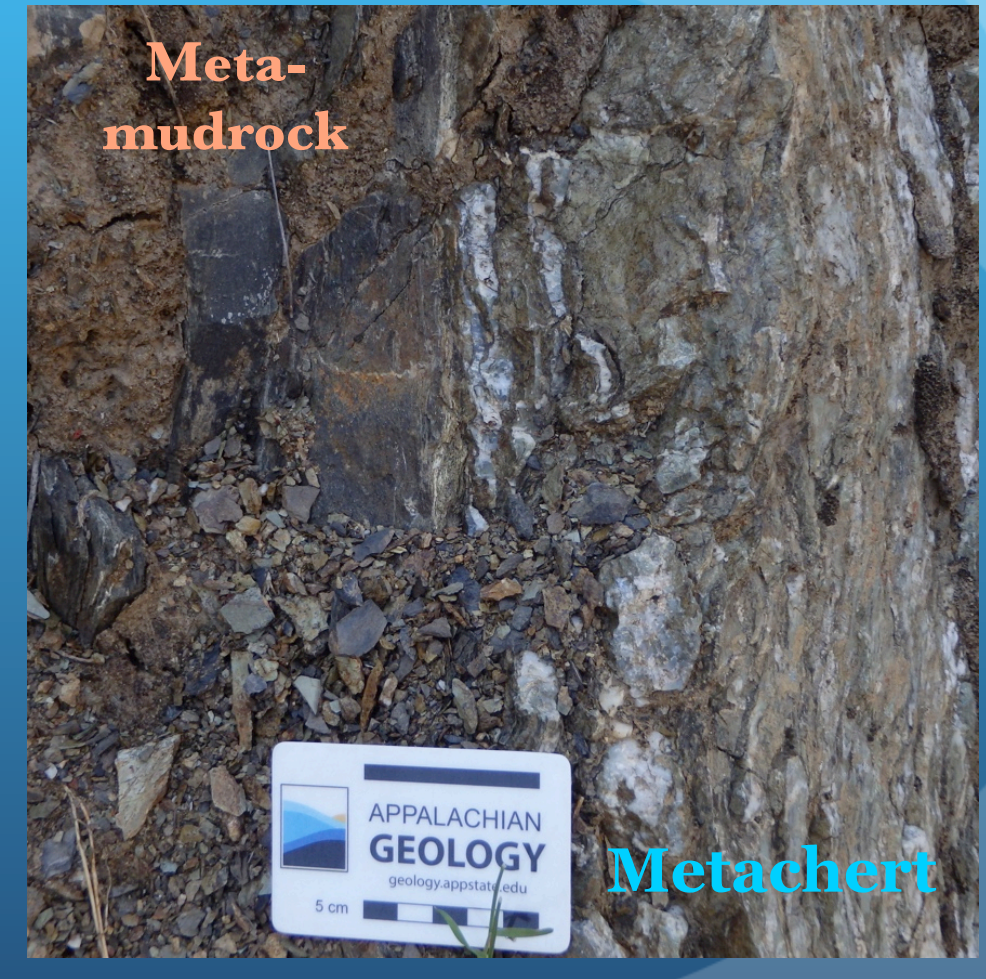

Del Puerto 


\section{which appears to be the case in this example.}
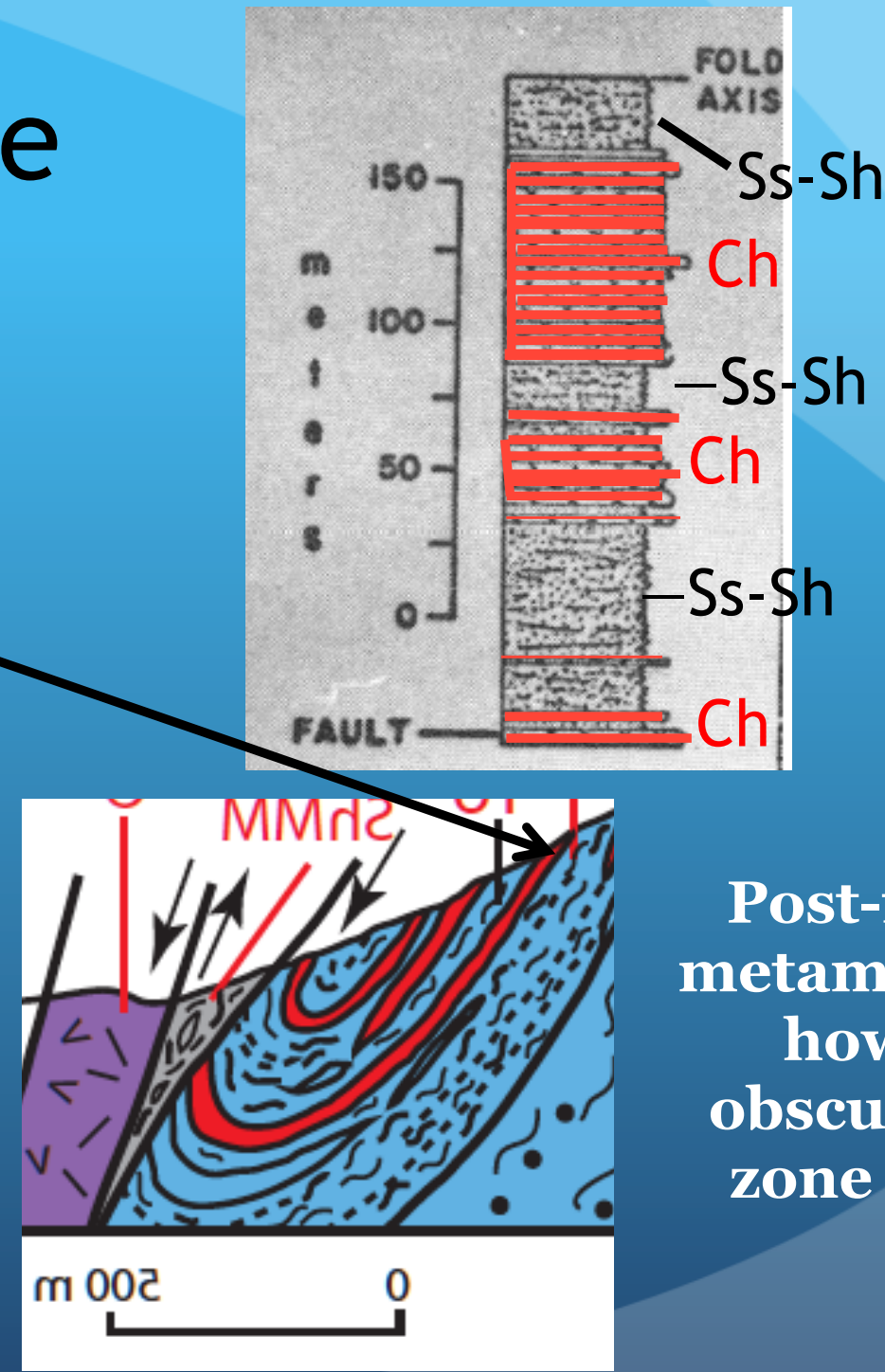

Post-faulting metamorphism, however, obscures fault zone fabrics. 
- If interlayered chert-sandstone sections exist, and I believe they do,

(1) they demand expanded or alternative explanations of or for the traditional, singular basite-chert-sandstone+mudrock stratigraphy of the conceptual OPS, and 
- (2) they require that stratigraphic chertsandstone sections be distinguished from fault-bounded inter-terrane and intraterrane tectonostratigraphic OPS units during Franciscan terrane or accretionary unit evaluations. We cannot assume a fault beneath every chert or metabasite with structurally overlying sandstone. 
- The answers cannot lie in the highly metamorphosed sections in the Eastern Franciscan, where fault rocks are metamorphosed.

- Evaluations of interbedding need to be conducted in western, unmetamorphosed Franciscan accretionary units, like the Marin Headlands and Nicasio Reservoir AUs. 


\section{CONCLUSIONS:}

- We need much more information on chert stratigraph deposition, and age correlations, plus plate histories an regional tectonics, to resolve conundrum 1.

- Many Franciscan terranes are pseudo-terranes. 


\section{Continued \\ CONCLUSIONS:}

- Most chert sections in the Franciscan Complex are parts of OPS sections that have been faulted into various rock units

- Some Franciscan cherts appear to be interlayered with sandstone and shale. The details of these occurrences must be evaluated to assess their significance for Franciscan architecture and history - resolving conundrum 2. 


\section{Thank you for your attention.}

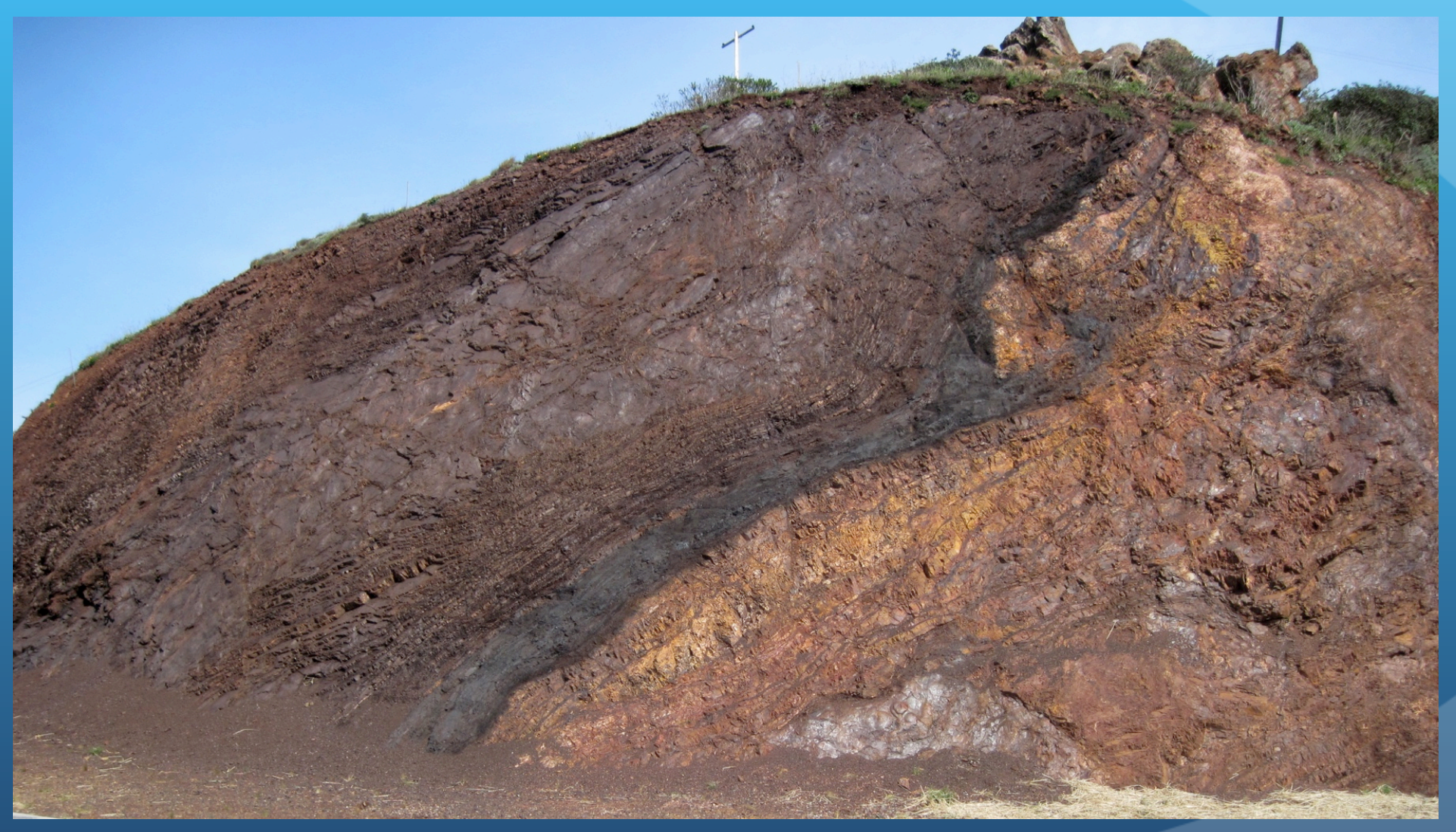

